\title{
Influence of Service Quality Dimensions of Islamic Banks on Customer Satisfaction and Their Impact on Customer Loyalty
}

\author{
Afifah$^{1}$, Nurul Alfiah Kurniawati ${ }^{2}$ \\ ${ }^{1}$ Airlangga University \\ ${ }^{2}$ University of Edinburgh \\ email: afifah-2019@feb.unair.ac.id,nurulalfiahkurniawati@ \\ gmail.com
}

\begin{abstract}
Strengthening Islamic banking funding is one of particular strategies in the Indonesian Islamic banking master plan for 2019-2024, as one of their expected outputs is to increase market share and customer satisfaction of Islamic banks. This study aims to identify influence of service quality dimensions on customer satisfaction and their impacts on customer loyalty in Islamic banks in Indonesia. This study used a quantitative approach. Its data were collected by an online questionnaire with five Likert scales randomly given to 136 customers from several Islamic banks who had direct transactions at the Islamic banks. The sampling technique of this study used a purposive sampling technique, and its analysis technique used Structural Equation Modeling based on Partial Least Square (SEM-PLS). The findings of this paper indicate that the dimensions of both compliance and responsiveness have significant influence on customer satisfaction and customer loyalty. Meanwhile, assurance, reliability, and empathy dimensions have no significant impacts on customer satisfaction and customer loyalty. Tangible dimension has significant influence on customer satisfaction but has no significant influence on customer loyalty. Customer satisfaction has a significant impact on customer loyalty.
\end{abstract}

Keywords: Islamic bank, CARTER model, customer satisfaction, customer loyalty 


\section{INTRODUCTION}

In the last ten years, Islamic banking in Indonesia has experienced proper growth, but this is not accompanied by its market share, as this has still reached $6.18 \%$ of the total banking market share in general until June 2020. Wahyuningsih (2014) explains that basically profits of a bank are entirely come from their customers, so this indicates that banking institutions will focus on how to get a larger number of customers to increase their market share. As a bank is a company that offers services to consumers, one of ways of to increase the number of its consumers or customers is to provide better service quality to provide satisfaction for customers until they will ultimately be loyal to the bank.

Ratnasari, R.T., et al (2020) states that improving service quality is very important for a company in gaining a competitive advantage. Investment to improve service quality will also lead to increasing profitability and market share (Rust, R.T. and Zahorik, A.J., 1993). In addition, in service industries around the world, discussions of service quality remain important as a business strives to maintain a comparative advantage in its market. Banking financial institutions as one of financial services that compete in generally similar product market consider service quality as a main competitive weapon (Stafford, M.R., 1996), and they also may increase customer trust through mediation of customer satisfaction (Misbach, I. and Hadiwidjojo, D., 2013).

In a context of Islamic banking, scale measurements on service quality that has been conducted and widely applied by previous researchers is a CARTER model. This model is a development of a SERVQUAL model (Parasuraman, A., et al, 1998) that cannot be measured based on social and cultural aspects. Cronin dan Taylor (1992) criticize that the SERVQUAL model consisting of assurance, reliability, tangible, empathy, and responsiveness dimensions do not fully address religious compliance. Therefore, Othman dan Owen (2001) develop the CARTER model by adding a new dimension to the SERVQUAL model. One of the added dimensions is about consumer attitudes towards religious beliefs that can influence their decision to buy a product or service. This 
dimension is compliance referring to obey on a business entity or product based on religious principles. Thus, in the CARTER model there are six dimensions; the are compliance, assurance, reliability, tangible, empathy, and responsiveness. This differs from the SERVQUAL model only in the compliance dimension, especially compliance in upholding Islamic religious principles in its operations.

The compliance dimension is a unique characteristic tried to be measured by the CARTER model. The compliance is an interesting issue to discuss because this dimension proves not to be an absolute factor that encourages customers in several countries with Muslim majority populations to be satisfied when using Islamic banking services. The compliance is considered as the most substantial factor by Islamic banking customers in Kuwait (Othman, A.Q. and Owen, L., 2001), Malaysia (Shafie, S., et al, 2004) and Indonesia (Ciptono and Sofiyanti, 2007; Ramdhani et al., 2011). However, these findings still can be debated because other results report that reliability dimension is the most influential service quality dimension in Malaysia (Amin dan Isa, 2008; Osman et al., 2009) and responsiveness dimension is the most influential in Indonesia (Misbach, I. and Hadiwidjojo, D., 2013). In Saudi Arabia, as the largest center of Islamic civilization in the world, the compliance dimension is a factor that has very low influence on customer satisfaction in using Islamic banking services (Loone., Aldawood., and Bhat, 2017). Meanwhile in other countries such as Pakistan, England, United Arab Emirates (Rehman, K-u. and Khattak, N., 2010) and Bahrain (Janahi, M.A. and Almubarak, M., 2015), assurance dimension is the most influential to encourage customer satisfaction on Islamic banking services. These different results of the studies regarding the service quality dimensions in several countries are reasonable because each country has different historical and cultural backgrounds. However, the results of several studies in Malaysia and Indonesia show inconsistent results.

Based on the discussions above, the author aims to study further about the influence of the service quality dimensions of Islamic banks on customer satisfaction and their impacts on 
customer loyalty. This study is to contribute to improve service quality for customer satisfaction and to create customer loyalty on Islamic banking financial institutions in Indonesia, so that the market share of Islamic banks will continue to increase.

\section{LITERATURE REVIEW Service Quality Dimensions}

Zeithaml, et al (1996) define service as acts, processes, and provided performances that are co-produced or co-created by a particular entity/person. In other words, service is an act or performance, conducted by a party and offered to the other parties, which is essentially intangible and does not contribute to ownership. Then quality, according to Cullen and Hollingum (1987), is a condition like what a product says. In a sense, the product is good and appropriate to what is offered. Service quality is used as a measurement of how good the level of service is in accordance to customer expectations. Lewis and Booms (1983) also express that the service quality can be realized by fulfilling customer needs and desires and accuracy of its delivery to keep balance with customer expectations. Febriandika N.R., et al (2020) said that customer loyalty can be built by improving the customer experience. One of customer experience is service quality.

Islamic banking is different from conventional banking, especially in three important aspects: no extra interest income $(\underline{\text { riba }})$, no interest rates, and Islamic principles as a practice in every economic activity (Ebrahimi, M.R. and Moghadam, A.H., 2012). Therefore, Othman and Owen develop (2001) the CARTER model to define and measure the service quality in Islamic banking. This is because the SERVQUAL model is considered inappropriate to be applied in Islamic banking because there is a compliance dimension that must be upheld by Islamic banking as its economic activities are applied based on Islamic principles. Therefore, if the SERVQUAL model only have five dimensions, the CARTER model developed by Othman and Owen add one dimension, the compliance (Islamic compliance). Thus, the CARTER model consists of six dimensions to measure the service quality. The six dimensions are in the following: 
1. Compliance is ability to follow Islamic principles applied in Islamic banking operations (Othman, A.Q. and Owen, L., 2001). This means that all products or services developed and offered by Islamic banks must follow Islamic law. In addition, all business transactions must use a revenue sharing system and prohibit interest on funding and loans. Ullah asserts (2014) that some Islamic banks cannot follow the Islamic law comprehensively because of systemic factors such as economic system, government regulations, and lack of research and development. However, Amin and Isa (2008) insist that Islamic banks should always improve relationships based on customer trust regarding Islamic compliance principles. In previous empirical studies, compliance was considered as one of the most significant determinants of service quality in Islamic banking (Othman and Owen, 2001; and Osman, et al, 2009).

2. Assurance is knowledge and politeness of Islamic banking employees as well as their communication skills to provide trust and conviction to customers (Othman, A.Q. and Owen, L., 2001). Therefore, excellent service quality requires Islamic bank employees who are polite, skilled and competent, and it also requires them to work and provide solutions of financial problems experienced by customers (Janahi, M.A. and Almubarak, M., 2015). The assurance becomes an important dimension of service quality to satisfy the Islamic banking customers (Janahi and Almubarak, 2015; and Khamis, et al, 2008).

3. Reliability is ability to provide services which are suitably promised, reliable, accurate, and trustworthy by customers (Othman, A.Q. and Owen, L., 2001). The reliability can make Islamic banks more efficient and create a higher level of customer satisfaction (Janahi, M.A. and Almubarak, M., 2015). Some studies also found that reliability is the most influential dimension experienced by Islamic banking customers (Amin and Isa, 2008; Osman et al, 2009; and Zaim, et al, 2010). 
4. Tangible is physical evidence associated with the existence or appearance of physical facilities, equipment, personnel, and communication materials (Othman, A.Q. and Owen, L., 2001). Tangible is physical appearance, equipment, personnel, and communication materials, and it can also be related to a company's ability to show its existence to external parties (Lupiyoadi, 2001). Janahi and Almubarak (2015) argues that tangible includes convenience of location, design of physical facilities, materials, and uses of communication equipment. According to Qureshi et al. (2012), service quality can work well in Islamic banking when supported by tangibility elements. Tangible is an important aspect of Islamic banking that can lead to customer satisfaction (Zaim, H., et al, 2010).

5. Empathy is a care, an individual's care of an Islamic bank to its customers (Othman, A.Q. and Owen, L., 2001). This dimension is a profile of Islamic bank employees who can offer special attention to customers. Empathy has proven to be a very important dimension of service quality in Islamic banking which can ultimately produce customer satisfaction (Qureshi et al., 2012; Othman and Owen, 2001; Osman et al, 2009).

6. Responsiveness is ability to help customers and provide services quickly and provide clear information (Lupiyoadi, 2001). Responsiveness produces a willingness to help customers and provide fast services (Othman, A.Q. and Owen, L., 2001). Janahi and Almubarak (2015) convey that fast and efficient frontliner staff and availability of bank branches and ATMs are good examples of responsiveness. Responsiveness is an essential dimension that must be considered by Islamic banks to increase levels of customer satisfaction (Misbach, I. and Hadiwidjojo, D., 2013).

The six dimensions of the CARTER model is an extension of the Parasuman's SERVQUAL model (Parasuraman et al., 1988). However, because the model has no dimension that measures levels of compliance related to Islamic principles, Othman and Owen (2001) develop a CARTER model to measure the service 
quality of Islamic banking. This paper will test how quality dimensions of CARTER model influence customer satisfaction and loyalty of Islamic banking.

\section{Customer Satisfaction}

In the traditional concept, Customer is everyone who buys and uses that company's products or services. In a modern concept, customer falls into two categories; internal or external Customer (Sudarwati., and Yani, B.A., 2021). Customer satisfaction is one of the most important strategic elements in any organization. This is because any business relies on customers as a major source of income (Rehman, K-u. and Khattak, N., 2010). Customer satisfaction is one of the important factors of a company's success. To achieve high customer satisfaction, a company must understand when and how they satisfy their customers by their products and services (Syauqi) M., Ratnasari. R.T., Herianingrum. S., 2018).

Modern marketing believes that business survival depends on ability to fulfill customer needs and satisfaction. It is assumed that customer satisfaction attracts loyalty and retention of customers; therefore, it will increase profitability (Okumus, H.S. and Genc, E.G., 2013). Financial institutions focus on improving customer satisfaction to achieve their goals by improving their service quality and products (Ahmed, A. and Rehaman, K-u., 2010). Customer satisfaction is very important for banks or companies as a famous slogan always says that customers are a king who needs to be served as best as possible (Kashmir, 2004). Kotler (2005) defines that satisfaction is a person's feeling of pleasure or disappointment derived from a comparison between his/her impression on performance and results of a product and his/her expectations. Meanwhile, Tjiptono (2005) mentions that customer or consumer satisfaction is an evaluation of buyers when a chosen alternative is at least same or above customer expectations; while, dissatisfaction occurs when the results do not fulfill the expectations. However, achieving customer satisfaction is not easy. Being a subjective evaluation, customer satisfaction is a main challenge for a company in understanding, achieving, and 
maintaining satisfaction among its customers (Ratnasari. R.T., Gunawan. S., and Mawardi. I., 2020).

In a disconfirmation paradigm, customer satisfaction is understood as an emotional reaction or a customer feeling to different assessments between performance and expectations (Oliver, 1980) in (Ratnasari. R.T., Gunawan. S., and Mawardi. I., 2020). Particularly, the disconfirmation can be positive if a product exceeds expectations as a consumer will be happy, or the disconfirmation can be negative if it is not in accordance to expectations as a consumer will be dissatisfied; if it fulfils the expectations, the consumer will be satisfied (Kotler, P., 2005). On a positive side, satisfied consumers will become loyal and will make buybacks, or the satisfied consumers will promote mouth to mouth (Schiffman. L. dan L, Kanuk., 2008). In this paper the author examines how quality service influences customer satisfaction and how customer satisfaction influences customer loyalty. Indicators of customer satisfaction used in this study refers to a theory of Geyskenz et al. (1999), especially economic satisfaction (including satisfaction with a concept of revenue sharing, administrative costs, product costs, etc.) and noneconomic satisfaction (including satisfaction with an existing system in Islamic banks, Islamic bank products, and provided facilities).

\section{Customer Loyalty}

The concept of customer loyalty in the service industry is considered as an important point in marketing literatures (Caceres, R.C. and Paparoidamis, N.G., 2007). Customer loyalty is company's ability to continually win protection from certain customers over other competitors. It is a sustainable process that does not end with satisfaction of customer needs, but this continues with establishment of long-term recurring purchasing relationships with customers respecting to a particular brand (Tweneboah-Koduah, E. and Farley, Y.D., 2015). Lam, et al. (2004) explain that customer loyalty is a recurring protection and a recommendation of a service provider to other customers. In recent years, customer loyalty to bank services has become a 
focal point for marketing teams and researchers. This is because bank's ability to attract and maintain customers in a long term is strongly linked to their profitability (Keisidou, E., et al., 2013). Therefore, banks need to implement a customer loyalty program.

Following existing literatures, Ganiyu et al. (2012) reveal that customer loyalty is demonstrated by buying back products despite existing attractive competitive alternatives that may encourage the customers to try competitor products, supporting and promoting company's goods or services to others, and providing feedback related to a company's performance. The most important benefit of having loyal customers is that it allows a business to save some various expenses, as attracting new customers is more expensive than retaining existing customers (Dick, A.S. and Basu, K., 1994). In addition, customer loyalty is considered to contribute to increasing revenue (Hennig-Thurau, T., et, al., 2002), as loyal customers will purchase more of their main goods, services, brands (Chaudhuri, A. and Holbrook, M.B., 2001), and other variations of goods or services (Shoemaker, S. and Lewis, R.C., 1999). Estiri et al. (Estiri, et al., 2011) state that customer satisfaction and service quality are very significant for marketing theory and practice, and they are considered as key predictors of customer loyalty. These findings are in line with a study of Ofori et al. (2017) illustrating that service quality is a very important determinant of trust and satisfaction that will eventually impact on customer loyalty. Loyalty indicators used in this study refer to theories of Kyle et al. (2010), Zeithaml et al. (1996), and Kotler (2005), especially repurchase intention (repurchase of services or products), word of mouth (recommending to others), and retention (strong commitment to provided products or services).

\section{Relationships between variables}

1. Service Quality Dimensions and Customer Satisfaction

Service quality and customer satisfaction are interrelated concepts (Hossein, V. and Sahel, F., 2013). However, factors that influence customer satisfaction based on provided service quality may vary in some countries (Giese, J.L. and Cote, J.A., 2002). Some studies have found a positive relationship between 
service quality provided by banks and customer satisfaction (Slacket et al., 2020; Khamis and AbRashid., 2018). Khamis and AbRashid (2018) also demonstrate that service quality plays an important role in customer satisfaction. As a result, company can increase its market share by improving it service quality. Othman and Owen (2001), as well as Osman, et al. (2009) found a significant positive relationship between service quality dimensions (especially, compliance) and customer satisfaction.

H1: Compliance significantly influences customer satisfaction

Assurance is knowledge and politeness of employees and ability of a company and its employees to inspire trust and conviction (Ratnasari. R.T., and Aksa. M.H., 2011). Furthermore, Famiyeh, S., et al. showed (2017) that assurance has no positive and significant influence on customer satisfaction. Meanwhile Akhtar, M.N. et al. (2011) Osman, et al., (2009), and Khamis, et al. (2018) found a significant positive relationship between assurance and satisfaction.

$\mathrm{H} 2$ : Assurance significantly influences customer satisfaction

Some studies have pointed out that there is a significant positive relationship between reliability and customer satisfaction (Famiyeh, S., et al., 2017; Othman and Owen, 2001; Khamis and AbRashid, 2018).

H3: Reliability significantly influences customer satisfaction

Zaim, et al. (2010) argues that tangible dimension is an important factor that influences customer satisfaction. Famiyeh, S., et al. (2017) also indicates that there is a significant positive relationship between the tangible dimension and customer satisfaction.

H4: Tangible significantly influences customer satisfaction

Khamis, et al., (2018), Famiyeh, S., et al., (2017), and Osman, et al., (2009) found a significant positive relationship between empathy dimension and customer satisfaction. Zaim, 
et al. (2010) also expresses that empathy dimension is the most influential service quality for customer satisfaction.

H5: Empathy significantly influences customer satisfaction

Several studies found a significant positive relationship between responsiveness and customer satisfaction (Othman and Owen, 2001; Osman, et al, 2009; Akhtar, M.N., 2011; Khamis and AbRashid, 2018). Meanwhile, Famiyeh, S., et al (2017) states that responsiveness does not have a positive and significant influence on customer satisfaction.

H6: Responsiveness significantly influences customer satisfaction

\section{Service Quality Dimensions and Customer Loyalty}

Customer loyalty is suggested to consist of two different dimensions, loyalty attitude (willingness to recommend service to others) and loyalty behavior (repeat purchase) (Kyle, G., et al, 2010), and it is an output of a positive service experience (Zeithaml, V.A., et al, 1996). Some scholars argue that service quality leads to customer loyalty (Dick and Basu, 1994; Ladhari, 2009) and positively influences customer loyalty in both repurchase dimension and word of mouth (Slack et al., 2020; Asnawi et al., 2019). Also, it negatively relates to customer disloyalty (Kelley et al., 1993). Next, Parasuraman et al. (1998) convey that service quality plays an important role to increase customer loyalty. Amin (2013) indicates a direct and very significant relationship between service quality and customer loyalty. Dandis and Wright (2020) as well as Fauzi and Suryani (2018) conclude that compliance has a positive and significant influence on customer loyalty. H7: Compliance significantly influences customer loyalty

Slack, et al. (2020) state that assurance has no significant influence on customer loyalty. Meanwhile, Ren and Lam (2016) indicates a positive and significant relationship between assurance and customer loyalty. H8: Assurance significantly influences customer loyalty 
Murray and Howat, (2002) mention that reliability is the most important dimension of service quality on customer loyalty. Ren and Lam (2016) then also show a positive and significant relationship between reliability and customer loyalty. Otherwise, Slack, et al. (2020) argues that reliability has no significant influence on customer loyalty.

H9: Reliability significantly influences customer loyalty

Lee et al. (2010) suggest that tangible is the most important dimension of service quality in predicting customer loyalty. Bloemer et al. (1999) also state that tangible can positively influence customer loyalty.

H10: Tangible significantly influences customer loyalty

Ioannis and Lymperopoulos (2009) found a positive influence between empathy and customer loyalty. Similarly, Slack, et al. (2020) indicate that empathy has a positive and significant influence on customer loyalty.

H11: Empathy significantly influences customer loyalty

Bloemer et al. (1999) and Slack, et al. (2020) argue that responsiveness positively and significantly influences customer loyalty.

H12: Responsiveness significantly influences customer loyalty

\section{Customer Satisfaction and Customer Loyalty}

Some scholars argue that customer satisfaction can lead to loyalty (Slack et al., 2020, Casidy and Wymer, 2015; Kasiri et al., 2017). There is a positive relationship between customer satisfaction and repurchase (Kasiri, et al, 2017), and also there is a positive relationship between customer satisfaction and word of mouth promotion (Kasiri et al., 2017; Pedragosa and Correia, 2009). In addition, Chen and Wang (2009) point out that satisfied customers are more likely to be loyal customers, buy back, give a positive word of mouth, and reduce their price sensitivity. Slack, et al. (2020) demonstrate that there is a positive relationship between customer satisfaction and loyalty; the higher the satisfaction is 
experienced, the more it influences customer loyalty. Omoregie et al. (2018) also state that customer satisfaction has the most significant influence on customer loyalty.

H13: Customer satisfaction significantly influences customer loyalty

\section{METHODS}

A method used in this study was an explorative quantitative approach. Ameasurement method of this study used questionnaires as a tool to determine the influence among variables in this study. Respondents in this study were people who had Islamic bank accounts and had conducted transactions directly at the banks.

The methods in this study were conducted in two steps. The first step is testing the questionnaire material. At this step, the questionnaires were distributed to 50 respondents to test whether each question in the questionnaires has been understood or confusing. In the second step, the distribution of questionnaires was continued on 80 respondents who met the criteria as mentioned above.

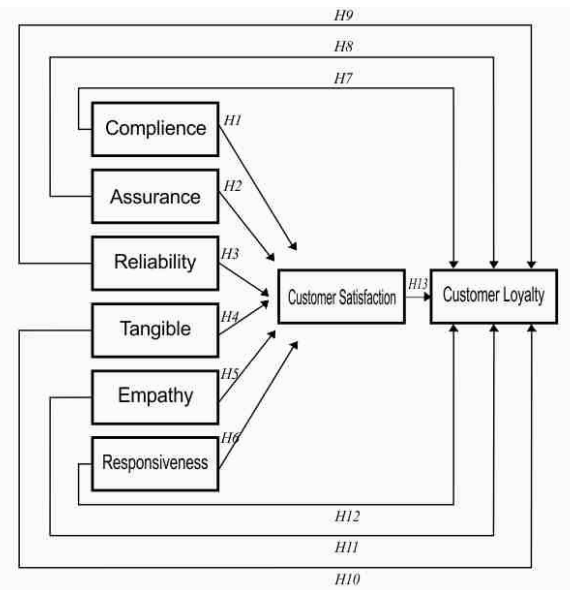

Figure 1 Conceptual Model

Thus, the respondents in this study were 136 respondents. Furthermore, a sampling was conducted by using a non-probability sampling technique with a purposive sampling, a sampling 
with special considerations to obtain more representative data (Sugiyono, 2009). Then, an analysis technique in this study applied Structural Equation Modeling based on Partial Least Square (SEM-PLS), a model of structural equations based on components or variants (Ghozali, I. Latan, H., 2012). This analysis technique was also conducted in two steps. The first was conducting a measurement model test to determine validity and reliability of constructs of each indicator. The second was conducting a structural model test to determine the influence among the variables.

\section{RESULTS AND DISCUSSION}

SEM-PLS is an analysis method not based on many assumptions, but this structural equation model is based on components or variants (Ghozali, I. Latan, H., 2012). The SemPLS is used to confirm a theory and explain relationships among latent variables. Sem-PLS processing by using Smart-PLS is performed in two steps. The first step is conducting a measurement model test to test validity and reliability of the constructs of each indicator. Then in the second stage, conducting a structural model test is to determine whether influence among the latent variables occur or not.

\section{Measurement Model Assessment}

The measurement models are evaluated based on the reliability and validity of the measurement instruments. Reliability is assessed by using cronbach's alpha and composite reliability. Henseler et al. (2009) recommend that cronbach's alpha reliability and composite reliability values can be considered reliable if they are above 0.7 . The table below indicates that all constructs are reliable because values of cronbach's alpha and composite reliability are above 0.7 .

Furthermore, the validity measurement is assessed by using Average Variance Extracted (AVE). Henseler, et al. (2009) suggest that an instrument can be valid if the AVE of each instrument in the model is above 0.5. The table below demonstrates that all constructs are valid. This is indicated by AVE values above 0.5 . 
Table 1. Results of reliability and validity tests

\begin{tabular}{lcccc}
\hline \multicolumn{1}{c}{ Constructs } & $\begin{array}{c}\text { Cronbach's } \\
\text { Alpha }\end{array}$ & rho_A & $\begin{array}{c}\text { Average } \\
\text { Composite } \\
\text { Reliability }\end{array}$ & $\begin{array}{c}\text { Variance } \\
\text { Extracted } \\
\text { (AVE) }\end{array}$ \\
\hline Insurance & 0.880 & 0.885 & 0.917 & 0.735 \\
Compliance & 0.747 & 0.752 & 0.840 & 0.569 \\
Customer & 0.940 & 0.944 & 0.950 & 0.678 \\
Loyalty & & & & \\
Customer & 0.931 & 0.940 & 0.944 & 0.708 \\
Satisfaction & & & & \\
Empathy & 0.903 & 0.912 & 0.933 & 0.776 \\
Reliability & 0.850 & 0.850 & 0.899 & 0.690 \\
Responsiveness & 0.953 & 0.953 & 0.966 & 0.876 \\
Tangible & 0.820 & 0.822 & 0.882 & 0.651 \\
\hline
\end{tabular}

\section{Structural Model Assessment}

\section{Hypothesis Testing}

Below is estimated values of each relationship among the research variables. Based on the table, the results of hypothesis tests can be interpreted as follows:

- The estimated coefficient value between compliance and customer satisfaction is 0.259 . The coefficient value indicates that there is a positive relationship between compliance and customer satisfaction. The higher the compliance level, the higher the level of customer satisfaction. Then, vice versa, the lower the compliance level, the lower the level of customer satisfaction. Based on $t$ value, the significance value is $0.005(p<0.05)$ so, there is a significant influence between compliance and customer satisfaction.

- The coefficient value of assurance of customer satisfaction is 0.044 . The coefficient value indicates a positive relationship between assurance and customer satisfaction. The higher the assurance level, the higher the level of customer satisfaction. Then, vice versa, the lower the assurance level, the lower the level of customer satisfaction. Based on $t$ value of 0.642 ( $p>$ 
0.05), there is no significant influence between assurance on customer satisfaction.

Table 2. Estimated variable coefficient values

\begin{tabular}{|c|c|c|c|c|}
\hline $\begin{array}{l}\text { Hypothesis } \\
\text { Relationship }\end{array}$ & $\begin{array}{c}\text { Original } \\
\text { sample } \\
(0) \\
\end{array}$ & $\begin{array}{c}\text { Statistic } \\
t(0 / \\
\text { STDEV) }\end{array}$ & $\begin{array}{c}\text { Value } \\
\mathbf{P}\end{array}$ & $\begin{array}{l}\text { Hypothesis } \\
\text { accept }\end{array}$ \\
\hline $\begin{array}{l}\text { Compliance } \\
\rightarrow \text { Customer } \\
\text { satisfaction }\end{array}$ & 0.259 & 2.857 & 0.004 & Accepted \\
\hline $\begin{array}{l}\text { Assurance } \\
\rightarrow \text { Customer } \\
\text { satisfaction }\end{array}$ & 0.044 & 0.463 & 0.644 & Rejected \\
\hline $\begin{array}{l}\text { Reliability } \\
\rightarrow \text { Customer } \\
\text { satisfaction }\end{array}$ & 0.047 & 0.403 & 0.687 & Rejected \\
\hline $\begin{array}{l}\text { Tangible } \rightarrow \\
\text { Customer } \\
\text { satisfaction }\end{array}$ & 0.250 & 2.918 & 0.004 & Accepted \\
\hline $\begin{array}{l}\text { Empathy } \rightarrow \\
\text { Customer } \\
\text { satisfaction }\end{array}$ & -0.023 & 0.200 & 0.842 & Rejected \\
\hline $\begin{array}{l}\text { Responsiveness } \\
\rightarrow \text { Customer } \\
\text { satisfaction }\end{array}$ & 0.358 & 2.468 & 0.014 & Accepted \\
\hline $\begin{array}{l}\text { Compliance } \\
\rightarrow \text { Customer } \\
\text { loyalty }\end{array}$ & 0.224 & 2.283 & 0.023 & Accepted \\
\hline $\begin{array}{l}\text { Assurance } \\
\rightarrow \text { Customer } \\
\text { loyalty }\end{array}$ & 0.016 & 0.170 & 0.865 & Rejected \\
\hline $\begin{array}{l}\text { Reliability } \\
\rightarrow \text { Customer } \\
\text { loyalty }\end{array}$ & -0.075 & 0.750 & 0.454 & Rejected \\
\hline
\end{tabular}




\begin{tabular}{|c|c|c|c|c|}
\hline $\begin{array}{l}\text { Hypothesis } \\
\text { Relationship }\end{array}$ & $\begin{array}{c}\text { Original } \\
\text { sample } \\
(\mathbf{O}) \\
\end{array}$ & $\begin{array}{c}\text { Statistic } \\
t(0 / \\
\text { STDEV) }\end{array}$ & $\begin{array}{c}\text { Value } \\
\mathbf{P}\end{array}$ & $\begin{array}{l}\text { Hypothesis } \\
\text { accept }\end{array}$ \\
\hline $\begin{array}{l}\text { Tangible } \rightarrow \\
\text { Customer } \\
\text { loyalty }\end{array}$ & 0.099 & 1.029 & 0.304 & Rejected \\
\hline $\begin{array}{l}\text { Empathy } \rightarrow \\
\text { Customer } \\
\text { loyalty }\end{array}$ & -0.023 & 1.189 & 0.235 & Rejected \\
\hline $\begin{array}{l}\text { Responsiveness } \\
\rightarrow \text { Customer } \\
\text { loyalty }\end{array}$ & 0.524 & 4.252 & 0.000 & Accepted \\
\hline $\begin{array}{l}\text { Customer } \\
\text { satisfaction } \\
\rightarrow \text { Customer } \\
\text { loyalty }\end{array}$ & 0.289 & 3.069 & 0.002 & Accepted \\
\hline
\end{tabular}

- $\quad$ Based on the estimated coefficient value by 0.047 , there is a positive relationship between reliability and customer satisfaction. The higher the reliability level, the higher the customer satisfaction level. Then, vice versa, the lower the reliability level, the lower the customer satisfaction level. Based on $t$ value of $0.666(p>0.05)$, there is no significant influence between reliability and customer satisfaction.

- The tangible coefficient value of customer satisfaction is 0.250 . The value shows a positive relationship between tangible and customer satisfaction. The higher the tangible level, the higher the level of customer satisfaction. Then, vice versa, the lower the tangible level, the lower the level of customer satisfaction. Based on $t$ value of $0.005(p<0.05)$, there is a significant influence between tangible and customer satisfaction.

- The estimated coefficient value of empathy and customer satisfaction is -0.023 . The coefficient value indicates that there is a negative relationship between empathy and customer satisfaction. Thus, the higher the empathy level, the 
lower the customer satisfaction level. Then, vice versa, the lower the empathy level, the higher the customer satisfaction level. Based on $t$ value, its significance value is 0.840 ( $p>$ $0.05)$ so, there is no significant influence between empathy and customer satisfaction.

- A value of responsiveness coefficient of customer satisfaction is 0.358 . The coefficient value indicates a positive relationship between responsiveness and customer satisfaction. The higher the responsiveness level, the higher the customer satisfaction level. Then, vice versa, the lower the responsiveness level, the lower the customer satisfaction level. Based on $t$ value of $0.009(p<0.05)$ so, there is a significant influence between responsiveness and customer satisfaction.

- Based on estimated coefficient value of 0.224 , There is a positive relationship between compliance and customer loyalty. The higher the compliance level, the higher the customer loyalty level. Then, vice versa, the lower the compliance level, the lower the customer loyalty level. Based on $t$ value of $0.045(p<0.05)$ so, there is a significant influence between compliance and customer loyalty.

- Assurance coefficient value of customer loyalty is 0.016 . The coefficient value indicates a positive relationship between assurance and customer loyalty. The higher the assurance level, the higher the customer loyalty level. Then, vice versa, the lower the assurance level, the lower the customer loyalty level. Based on $t$ value of $0.860(p>0.05)$ so, there is no significant influence between assurance and customer loyalty.

- Based on estimated coefficient of -0.075 , there is a negative relationship between reliability and customer loyalty. Thus, the higher the reliability level, the lower the customer loyalty level. Then, vice versa, the lower the reliability level, the higher the customer loyalty level. Based on $t$ value of 0.481 $(p>0.05)$ so, there is no significant influence between reliability and customer loyalty.

- Tangible coefficient value of customer loyalty is 0.099 . The value shows a positive relationship between tangible and 
customer loyalty. The higher the tangible level, the higher the customer loyalty level. Then, vice versa, the lower the tangible level, the lower the customer loyalty level. Based on $t$ value of $0.260(p>0.05)$ so, there is no significant influence between tangible and customer loyalty.

- The estimated coefficient value of empathy and customer loyalty is -0.153 . The coefficient value indicates that there is a negative relationship between empathy and customer loyalty. Thus, the higher the empathy level, the lower the customer loyalty level. Then, vice versa, the lower the empathy level, the higher the customer loyalty level. Based on $t$ value, the significance value is $0.249(p>0.05)$ so, there is no significant influence between empathy and customer loyalty.

- The responsiveness coefficient value of customer loyalty is 0.524 . The coefficient value indicates a positive relationship between responsiveness and customer loyalty. The higher the responsiveness level, the higher the customer loyalty level. Then, vice versa, the lower the responsiveness level, the lower the customer loyalty level. Based on $t$ value of $0.000(p<0.05)$ so, there is a significant influence between responsiveness and customer loyalty.

- Estimated coefficient value of customer satisfaction and customer loyalty is 0.289 . The coefficient value shows that there is a positive relationship between customer satisfaction and customer loyalty. The higher the customer satisfaction level, the higher the customer loyalty level. Then, vice versa, the lower the customer satisfaction level, the lower the customer loyalty level. Based on $t$ value, the significance value is $0.001(p<0.05)$ so, there is a significant influence between customer satisfaction and customer loyalty.

Results of SEM test demonstrate that compliance is a service quality dimension that mostly influence customer satisfaction after tangible dimension. Therefore, this supports the statement on $\mathrm{H} 1$ stating that there is a significant influence of compliance on customer satisfaction. In addition, the findings of this study also 
show that there is a positive relationship between compliance and customer satisfaction. This fact implies that in service satisfaction Islamic bank customers in Indonesia still consider the bank's compliance on Islamic principles in its operations. These results are in line with a study of Othman and Owen (2001) and a study of Osman, et al. (2009) indicating that there is a positive relationship and a significant influence between compliance and customer satisfaction. Islamic compliance is one of the most significant dimensions that contribute to the level of Muslim customer satisfaction in Islamic banks in Tanzania and (Khamis, F.M., and AbRashid, R., 2018) Indonesia (Asnawi, N., Sukoco, B.M. and Fanani, M.A., 2018). Khamis and AbRashid (2018) also state that compliance on Islamic principles is a determinant for customers in choosing Islamic banks.

Other findings show that there is a positive relationship between assurance, reliability and customer satisfaction, except empathy dimension with a negative relationship. However, these three dimensions have no significant influence on customer satisfaction. Thus, statements on $\mathrm{H} 2, \mathrm{H} 3$, and $\mathrm{H} 5$ are rejected. These statements convey that assurance, reliability, and empathy is not determinants of customer satisfaction of Islamic banks in Indonesia. The results of this study are different from a study of Amin and Isa (2008) finding that reliability is the most influential dimension in Malaysian Islamic banks, but these are in line with a study of Famiyeh, S., et al. (2017) arguing that assurance has no significant influence on customer satisfaction and there is a positive relationship between reliability and customer satisfaction. In addition, Suherman (2018) also asserts that empathy has no significant influence on customer satisfaction. According to him, customer satisfaction of BAS KC Banda Aceh is not influenced by empathy principles that has been applied but influenced by other factors such as qualified products, competitive price, or convenience experienced by customers.

In line with $\mathrm{H} 1$, tangible and responsiveness become the most influential dimension for customer satisfaction. In addition, there is a positive and significant relationship between the two 
dimensions and customer satisfaction. This relationship is supported by statements on $\mathrm{H} 4$ and $\mathrm{H} 6$, as $\mathrm{H} 4$ states that tangible dimension has a significant influence on customer satisfaction with an original sample value of 0.250 and H6 states that responsiveness dimension has a significant influence on customer satisfaction with an original sample value of 0.358 . These findings demonstrate that physical appearance, facilities, ability to help customers, fast service, and clear information are determinants of customer satisfaction of Islamic banks in Indonesia. Zaim, et al. (2010) note that tangible dimension is an important factor that influence customer satisfaction. Famiyeh,S., et al. (2017) also demonstrate that there is a significant positive relationship between tangible and customer satisfaction. In addition, the results of this study are also in line with some previous studies that also found a positive and significant relationship between responsiveness and customer satisfaction (Othman and Owen, 2001; Osman, et al, 2009; Akhtar, M.N., 2011; Khamis and AbRashid, 2018). The responsiveness is also considered as the most significant indicator influencing customer satisfaction at Libyan Islamic banks (Khafafa, A.J. and Shafii, Z., 2013).

Although tangible becomes the most influential dimension on customer satisfaction, but it has no significant influence on customer loyalty. In the CARTER model, dimensions that have positive and significant influence on customer loyalty are compliance and responsiveness. This is approved by statements on $\mathrm{H} 7$ and $\mathrm{H} 12$, as $\mathrm{H} 7$ states that compliance has a significant influence on customer loyalty and H12 states that responsiveness has a significant influence on customer loyalty. Results of this study are in accordance to studies by Souidena and Rani (2015) and by Lee and Ullah (2011) finding that religiosity is an important predictor for consumers to do repurchase decisions in Islamic banks. Similarly, these results strengthen a premise that religious commitment plays an important role to improve brand loyalty attitudes (Siala, 2013). In addition, Misbach and Hadiwidjojo (2013) also show that responsiveness of Islamic bank services is the strongest attraction for Islamic bank customers in Indonesia. 
Responsiveness is also considered as one of main dimensions of the CARTER model experienced by Islamic bank customers (Fauzi, A.A., and Suryani, T., 2018).

Furthermore, assurance, such as customer trust to save in Islamic banks, customer conviction on employee behavior, security experience when transacting, and service consistency of Islamic banks, is importantly needed to build a positive impression of customers to Islamic banks, but it has no significant influence on customer loyalty. In line with a study by Slack, et al. (2020) arguing that assurance has no significant influence on customer loyalty, tangible such as facilities and physical appearance remains important to build a positive customer impression on Islamic bank to increase customer loyalty although it does not have a significant influence. This is in line a study by Dandis and Wright (2020) stating that tangible has no significant influence on attitudinal loyalty. Reliability and empathy, such as Islamic bank reliability to fulfill promises, problem solving, employee's reliability to work, convenient service hours, and attention and patience of employees in serving customers, may not create a positive impression and not be a consideration for customers to become loyal customers in the bank. These findings are supported by a study of Slack, et al. (2020) showing that reliability has no significant influence on customer loyalty. Lone, et al. (2017) suggest that empathy needs to be considered by Islamic banks although it has no significant influence on customer satisfaction. These statements are supported by rejected statements on H8, H9, 10, and H11.

Similarly, the results of this study demonstrate that customer satisfaction as an intervening variable has a very significant positive influence on customer loyalty. This is evidenced by accepted statement on $\mathrm{H} 13$ stating that customer satisfaction has a significant influence on customer loyalty with a statistical $t$ value of 3,069 and $p$ value of 0.002 . These results are supported by some scholars who argue that customer satisfaction leads to loyalty (Slack et al., 2020, Casidy and Wymer, 2015; Kasiri et al., 2017) as the higher the satisfaction experienced by customers will influence customer loyalty (Slack, N., Singh, G., and Sharma, 
S., 2020). Chen and Wang (2009) also indicate that satisfied customers are more likely to be loyal, buy back, give a positive word of mouth, and reduce their price sensitivity. The statement is also supported by Omoregie et al. (2018) arguing that customer satisfaction has the most significant influence on customer loyalty.

Islamic bank as one of financial services competing in markets of similar products, service quality is a main competitive weapon (Stafford, M.R., 1996) and a way to improve customer conviction through mediation of customer satisfaction (Misbach, I. and Hadiwidjojo, D., 2013). In addition, one of specific strategies in the master plan of Islamic banking in Indonesia 2019-2024 is strengthening of Islamic banking funding; one of its expected outputs is to increase customer satisfaction and to increase customers of Islamic banks. Therefore, all hypotheses in this current study are suggested to be a reference for Islamic bank practitioners to realize these expectations. However, this study has limited data as its respondents only consist of 136 respondents, a very small number to represent all Islamic bank customers in Indonesia. This is because this study was conducted within a certain limited time.

\section{CONCLUSION}

These results of this study show that the CARTER Model is reliable and valid to test service quality of Indonesian Islamic banking. Tangible becomes a main factor of customer satisfaction to Islamic banks, followed by compliance and responsiveness dimension. Meanwhile, assurance and reliability dimensions have positive relationships to customer satisfaction. However, assurance, reliability, and empathy dimensions have no significant influence.

The results demonstrate that only compliance and responsiveness dimensions that have strong influence on customer loyalty in the CARTER model. Meanwhile assurance, tangible, and reliability dimensions have no significant influence. The results also confirm that customer satisfaction has a significant influence on customer loyalty. There is a very significant relationship between customer satisfaction and customer loyalty in Islamic 
banking of Indonesia as customer loyalty will increase more significantly if Islamic banks can increase customer satisfaction.

Nevertheless, factors that influence customer satisfaction and loyalty based on service quality may be different in each country (Giese, J.L. and Cote, J.A., 2002). According to Giese, et al., this is reasonable because of different cultures existing in each country.

\section{REFERENCES}

Ahmed, A. and Rehaman, K-u. (2010). An Imperical Investigation of Islamic Banking in Pakistan Based on Perception of Service Quality. International Journal of Business and Management, 1185-1193.

Akhtar, M.N., et al. (2011). Relationship Between Customer Satisfaction and Service Quality of Islamic Banks. World Applied Sciences Journal, 453-459.

Amin, M. and Isa, Z. (2008). An Examination of The Relationship Between Service Quality Perception and Customer Satisfaction a SEM Approach Towards Malaysian Islamic Banking. International, 191-209.

Amin, M., et al. (2013). Islamic Banks Contrasting The Drivers of Customer Satisfaction on Image, Trust, and Loyalty of Muslim and non-Muslim Customers In Malaysia. International Journal of Bank Marketing, 79-97.

Asnawi, N., Sukoco, B.M. and Fanani, M.A. (2018). Halal Products Consumption In International Chain Restaurants Among Global Moslem Consumers. International Journal of Emerging Markets, 1273-1290.

Bloemer, J., et al. (1999). Linking Perceived Service Quality and Service Loyalty: A Multi-Dimensional Perspective. European Journal of Marketing, 1082-1106.

Caceres, R.C. and Paparoidamis, N.G. (2007). Service Quality, Relationship Satisfaction, Trust, Commitment and Businessto-Business Loyalty. European Journal of Marketing, 836867. 
Casidy, R. and Wymer, W. (2015). The Impact of Brand Strength on Satisfaction, Loyalty and WOM: An Empirical Examination in The Higher Education Sector. Journal of Brand Management, 117-135.

Chaudhuri, A. and Holbrook, M.B. (2001). The Chain of Effects from Brand Trust and Brand Affect to Brand Performance: The Role of Brand Loyalty. Journal of Marketing, 81-93.

Chen, M.F. and Wang, L.H. (2009). The Moderating Role of Switching Barriers on Customer Loyalty in The Life Insurance Industry. The Service Industries Journal, 11051123.

Ciptono, W.S. and Sofiyanti, E. (2007). Adapting Islamic Banks' CARTER Model: An Empirical Study In Riau's Syariah Banks, Indonesia. Proceeding PESAT (Psikologi, Ekonomi, Sastra, Arsitek and Sipil), 120-127.

Cronin, J.J. and Taylor, S.A. (1992). Measuring Service Quality: A Reexamination and Extension. Journal of Marketing, 55.

Cullen, J. and Hollingum, J. (1987). Implementing Total Quality. Bedford: IFS Publications.

Dandis, A.O., and Wright, L.T. (2020). The Effects of CARTER Model on Attitudinal Loyalty in Islamic Banks. International Journal of Quality and Service Scinces, 149-171.

Dick, A.S. and Basu, K. (1994). Customer Loyalty: Toward an Integrated Conceptual Framework. Journal of the Academy of Marketing Science, 99-114.

Dick, A.S. and Basu, K. (1994). Customer Loyalty: Toward An Integrated Conceptual Framework. Journal, 99-113.

Ebrahimi, M.R. and Moghadam, A.H. (2012). A Survey to Recognize The Most Important Dimensions of The Service Quality of Iran Commercial Banks. Journal of Management Research, 303-317.

Estiri, et al. (2011). Determinants of Customer Satisfaction In Islamic Banking: Evidence From Iran. International Journal of Islamic and Middle Eastern Finance and Management, 
295-303.

Famiyeh, S., Darko, D.A., and Kwarteng, A. (2017). Service Quality, Customer Satisfaction, and Loyalty in The Banking Sector: The Moderating Role of Organizational Culture. International Journal of Quality \& Reliability Management, $1-36$.

Fauzi, A.A., and Suryani, T. (2018). Measuring The Effects of Service Quality By Using CARTER Model Towards Customer Satisfaction, Trust and Loyalty in Indonesian Islamic Banking. Journal of Islamic Marketing, 1-22.

Febriandika, N.R., Millatina, A.N., Luthfiyatillah., dan Hearianingrum, S. (2020). Customer E Loyalty of Muslim Millennials in Indonesia: Integrated Model of Trust, User Experience and Branding in E-Commerce Webstore. Association for Computing Machinery Journal, 369-376.

Ganiyu, R.A., et, al. (2012). Is Customer Satisfaction An Indicator of Customer Loyalty? Australian Journal of Business and Management Research, 14-20.

Geyskens.,et. al. (1999). A Meta-Analysis of Satisfaction in Marketing Channel Relationships. Journal of Marketing Research, 223-238.

Ghozali, I. Latan, H. (2012). Partial Least Square : Konsep, Teknik dan Aplikasi SmartPLS 2.0 M3. Semarang: Badan Penerbit Universitas Diponegoro.

Giese, J.L. and Cote, J.A. (2002). Defining consumer satisfaction. Academy of Marketing Science Review, 1-27.

Hennig-Thurau, T., et, al. (2002). Understanding Relationship Marketing Outcomes: An Integration of Relational Benefits and Relationship Quality. Journal of Service Research, 230-247.

Henseler, J., et al. (2009). The Use of Partial Least Squares Path Modeling In International Marketing. Advances in International Marketing, 277-319.

Hossein, V. and Sahel, F. (2013). Factors Influencing Customer 
Satisfaction With The Success Factors Identified In The Insurance Industry. African Journal of Business Management, 2026-2032.

Indonesia Halal LifeStyle Centre. (2019). Ekonomi Islam Global Laporan 2019/20; Ringkasan Eksekutif Memacu Revolusi Ekonomi Islam 4.0. Dubai: DinarStandard.

Ioannis, E.C. and Lymperopoulos, C. (2009). Service Quality Effect on Satisfaction and Word of Mouth In The Healthcare Industry. Managing Service Quality: An International Journal, 229-242.

Janahi, M.A. and Almubarak, M. (2015). The Impact of Customer Service Quality on Customer Satisfaction In Islamic Banking. Journal of Islamic Marketing, 595-604.

Kasiri, et al. (2017). Integration of Standardization and Customization: Impact on Service Quality, Customer Satisfaction, and Loyalty. Journal of Retailing and Consumer Services, 91-97.

Kasmir. (2004). Bank dan Lembaga Keuangan Lainnya. Jakarta: PT. Raja Grafindo Persada.

Keisidou, E., et al. (2013). Customer Satisfaction Loyalty and Financial Performance: A Holistic Approach of The Greek Banking Sector. International Journal of Bank Marketing, 259-288.

Khafafa, A.J. and Shafii, Z. (2013). Measuring The Perceived Service Quality and Customer Satisfaction In Islamic Bank Windows In Libya Based on Structural Equation Modelling (SEM). Afro, 57-71.

Khamis, F.M., and AbRashid, R. (2018). Service Quality and Customer's Satisfaction In Tanzania's Islamic Banks A Case Study at People's Bank of Zanzibar (PBZ). Journal of Islamic Marketing, 1-18.

Kotler, P. (2005). Manajemen Pemasaran Analisis, Perencanaan, dan Pengendalian. Jakarta: Erlangga.

Kyle, G., et al. (2010). The Effects of Service Quality on Customer 
Loyalty Within The Context of Ski Resorts. Journal of Park and Recreation Administration, 1-15.

Ladhari, R., et al. (2011). Determinants of Loyalty and Recommendation: The Role of Perceived Service Quality, Emotional Satisfaction and Image. Journal of Financial Services Marketing, 111-124.

Lam., et al. (2004). Customer Value, Satisfaction, Loyalty and Switching Costs: An Illustration From a Business-toBusiness Service Context. Journal of the Academy of Marketing Science, 293-311.

Lee, J.-K., et al. (2010). The Influence of Service Quality on Satisfaction and Intention: A Gender Segmentation Strategy. Sport Management Review, 54-63.

Lee, K. and Ullah, S. (2011). Customers'Attitude Toward Islamic Banking in Pakistan. International Journal of Islamic and Middle Eastern Finance and Management, 131.

Lewis, R.C. \& Booms, B.H. (1983). The Marketing Aspects of Service Quality” in Berry, L., Shostack, G. and Upah, G. (eds.). Emerging Perspectives on Services Marketing. Chicago: American Marketing Association Chicago.

Loone., Aldawood., and Bhat. (2017). Comparative Analysis of Customer Satisfaction towards Islamic and Conventional Banking: An Empirical Study From Saudi Arabia. International Review of Management and Marketing, 273280.

Lupiyoadi, R. (2001). Manajemen Pemasaran Jasa : Teori dan Praktik. Jakarta: Salemba Empat.

Misbach, I. and Hadiwidjojo, D. (2013). Islamic Bank Service Quality and Trust: Study on Islamic Bank In Makassar Indonesia. International Journal of Business and Management, 48-61.

Murray, D. and Howat, G. (2002). The Relationships Among Service Quality, Value, Satisfaction, and Future Intentions of Customers at An Australian Sports and Leisure Centre. 
Sport Management Review, 25-43.

Ofori., et al. (2017). Examining Customers' Continuance Intentions Towards Internet Banking Usage. Marketing Intelligence and Planning, 756-773.

Okumus, H.S. and Genc, E.G. (2013). Interest Free Banking In Turkey: A Study of Customer Satisfaction and Bank Selection. European Scientific Journal Edition, 144 -166.

Oliver, R. (1980). A Cognitive Model of The Antecedents and Consequences of Satisfaction Decisions. Journal of Marketing Research, 460-469.

Omoregie, et al. (2018). Factors Influencing Consumer Loyalty: Evidence from The Ghanaian Retail Banking Industry. International Journal of Bank Marketing, 1-24.

Osman, I., et al. (2009). Customers Satisfaction In Malaysian Islamic Banking. International Journal of Economics and Finance, 197-202.

Othman, A.Q. and Owen, L. (2001). The Multi Dimensionality of CARTER Model to Measure Customer Service Qaulity (SQ) In Islamic Banking Industry: A Study in Kuwait Finance House. International Journal of Islamic Financial Services, 1-12.

Parasuraman, A., et al. (1998). SERVQUAL: A Multiple-Item Scale for Measuring Consumer Perceptions of Service Quality. Journal of Retailing, 12-40.

Paul, J., Mittal, A., Srivastav, G. (2016). Impact of Service Quality on Customer Satisfaction in Private and Public Sector Banks. International Journal of Bank Marketing, 606-622.

Pedragosa, V. and Correia, A. (2009). Expectations, Satisfaction and Loyalty in Health and Fitness Clubs. International Journal of Sport Management and Marketing, 450-464.

Qureshi, M.I., Khan, A. and Zaman, K. (2012). Structural Investigation of Service Quality In Conventional and Islamic Banking In Pakistan. International Review of Management and, 99-105. 
Ramdhani, M.A., et al. (2011). The Influence of Service Quality Toward Customer Satisfaction of Islamic Sharia Bank. Australian Journal of Basic and Applied Sciences, 10991104.

Ratnasari, R.T., Gunawan, T., Septiarini, S., Fitrisia, D., Sylva, R., Kirana, A. and Kusuma, C. (2020). Customer Satisfaction Between Perceptions of Environment Destination Brand and Behavioural Intention. International Journal of Innovation, Creativity and Change, 472 - 487.

Ratnasari. R.T., dan Aksa. M.H. (2011). Manajemen Pemasaran Jasa. Bogor: Ghalia Indonesia.

Ratnasari. R.T., Gunawan. S., dan Mawardi. I. (2020). Emotional Experience on Behavioral Intention for Halal Tourism. Journal of Islamic Marketing, 1-18.

Rehman, K-u. and Khattak, N. (2010). Customer Satisfaction and Awareness of Islamic Banking In Pakistan. African Journal of Business Management, 662-671.

Ren, Y. and Lam, D. (2016). An Investigation Into The Link Between Service Quality Dimensionality and Positive Word-of-Mouth Intention In Mainland China. Journal of Marketing Communications, 513-523.

Rust, R.T. and Zahorik, A.J. (1993). Customer Satisfaction, Customer Retention, and Market Share. Journal of Retailing, 193-215.

Schiffman. L. dan L, Kanuk. (2008). Consumer Behaviour. Jakarta: PT. Indeks.

Shafie, S., et al. (2004). Adopting and Measuring Customer Service Quality (SQ) In Islamic Banks: A Case Study In Bank Islam Malaysia Berhad. Journal of Muamalat and Islamic Finance Research, 1-12.

Shoemaker, S. and Lewis, R.C. (1999). Customer Loyalty: The Future of Hospitality Marketing. International Journal of Hospitality Management, 345-370.

Siala, H. (2013). Religious Influences on Consumers' High- 
Involvement Purchasing Decisions. Journal of Services Marketing, 579-589.

Slack, N., Singh, G., and Sharma, S. (2020). The Effect of Supermarket Service Quality Dimensions and Customer Satisfaction on Customer Loyalty and Disloyalty Dimensions. International Journal of Quality and Service Sciences, 1-22.

Souiden, N. and Rani, M. (2015). Consumer Attitudes and Purchase Intentions Toward Islamic Banks: The Influence of Religiosity. International Journal of Bank Marketing, 143-161.

Stafford, M.R. (1996). Demographic Discriminators of Service Quality In The Banking Industry. Journal of Services Marketing, 6-22.

Sudarwati, and Yani, B.A. (2021). Analysis of Customer's Decision to Choose Sharia Banking in Surakarta. Journal of Islamic Economic Laws, 61-77.

Sugiyono. (2009). Metode Penelitian Administrasi. Bandung: Alfabeta.

Suherman, A. (2018). Analisis Kualitas Pelayanan dengan Model CARTER dan Pengaruhnya Terhadap Kepuasan Nasabah (Studi Pada PT Bank Aceh Syariah KC Banda Aceh). Banda Aceh: Fakultas Ekonomi dan Bisnis Islam UIN Ar-Raniry.

Syauqi. M., Ratnasari. R.T., Herianingrum. S. (2018). The Effects of Islamic Marketing Mix on Consumer Satisfaction and Consumer Loyalty. ICPS 2018 - 2nd International Conference Postgraduate School, 192-200.

Tjiptono, F. (2005). Manajemen Pemasaran dan Pemasaran Jasa. Malang: Bayu Media Publishing.

Tweneboah-Koduah, E. and Farley, Y.D. (2015). Relationship Between Customer Satisfaction and Customer Loyalty In The Retail Banking Sector of Ghana. International Journal of Business and Management, 249-262.

Ullah, H. (2014). Shari'ah Compliance In Islamic Banking An 
Empirical Study on Selected Islamic Banks In Bangladesh. International Journal of Islamic and Middle Eastern Finance and Management, 182-199.

Wahyuningsih. (2014). Tingkat Kualitas Pelayanan Dengan Model CARTER Pada BPD DIY Syariah. Skripsi. Yogyakarta: UIN Sunan Kalijaga.

Wong, A. and Sohal, A. (2003). Service Quality and Customer Loyalty Perspectives on Two Levels of Retail Relationships. Journal of Services Marketing, 495-513.

Zaim, H., et al. (2010). Service Quality and Determinants of Customer Satisfaction in Hospitals: Turkish Experience. The International Business \& Economics Research Journal, 51-58.

Zeithaml, V.A., et al. (1996). The Behavioural Consequences of Service Quality. Journal of Marketing, 31-46. 